\title{
STRENGTH CHARACTERISTICS OF SELF-CURING CONCRETE
}

\author{
M.V.Jagannadha Kumar ${ }^{1}$, M. Srikanth ${ }^{2}$, K. Jagannadha Rao $^{3}$ \\ ${ }^{1}$ Assoc Prof in Civil Engineering, NRIIT, Vijayawada (AP), India, mjaganjk@yahoo.com \\ ${ }^{2}$ Assoc Prof in Civil Engineering, Kakatiya Institute of Technology and Science, Warangal (AP), India, \\ msrik@rediffmail.com \\ ${ }^{3}$ Professor in Civil Engineering, Chaitanya Bharathi Institute of Technology, Hyderabad (AP), India, \\ kjagannadharao@yahoo.com
}

\begin{abstract}
Today concrete is most widely used construction material due to its good compressive strength and durability. Depending upon the nature of work the cement, fine aggregate, coarse aggregate and water are mixed in specific proportions to produce plain concrete. Plain concrete needs congenial atmosphere by providing moisture for a minimum period of 28 days for good hydration and to attain desired strength. Any laxity in curing will badly affect the strength and durability of concrete. Self-curing concrete is one of the special concretes in mitigating insufficient curing due to human negligence paucity of water in arid areas, inaccessibility of structures in difficult terrains and in areas where the presence of fluorides in water will badly affect the characteristics of concrete. The present study involves the use of shrinkage reducing admixture polyethylene glycol (PEG 400) in concrete which helps in self curing and helps in better hydration and hence strength. In the present study, the affect of admixture (PEG 400) on compressive strength, split tensile strength and modulus of rupture by varying the percentage of PEG by weight of cement from $0 \%$ to $2 \%$ were studied both for M20 and M40 mixes. It was found that PEG 400 could help in self curing by giving strength on par with conventional curing. It was also found that $1 \%$ of PEG 400 by weight of cement was optimum for M20, while $0.5 \%$ was optimum for M40 grade concretes for achieving maximum strength without compromising workability.
\end{abstract}

Index Terms: Self-curing concrete; Water retention; Relative humidity; Hydration; Absorption; Permeable pores; Sorptivity; Water permeability

\section{INTRODUCTION}

Proper curing of concrete structures is important to meet performance and durability requirements. In conventional curing this is achieved by external curing applied after mixing, placing and finishing. Self-curing or internal curing is a technique that can be used to provide additional moisture in concrete for more effective hydration of cement and reduced self-desiccation.

\subsection{Methods of self curing}

Currently, there are two major methods available for internal curing of concrete. The first method uses saturated porous lightweight aggregate (LWA) in order to supply an internal source of water, which can replace the water consumed by chemical shrinkage during cement hydration. The second method uses poly-ethylene glycol (PEG) which reduces the evaporation of water from the surface of concrete and also helps in water retention.

\subsection{Mechanism of Internal Curing}

Continuous evaporation of moisture takes place from an exposed surface due to the difference in chemical potentials (free energy) between the vapour and liquid phases. The polymers added in the mix mainly form hydrogen bonds with water molecules and reduce the chemical potential of the molecules which in turn reduces the vapour pressure, thus reducing the rate of evaporation from the surface.

\subsection{Significance of Self-curing}

When the mineral admixtures react completely in a blended cement system, their demand for curing water (external or internal) can be much greater than that in a conventional ordinary Portland cement concrete. When this water is not readily available, significant autogenous deformation and (early-age) cracking may result. Due to the chemical shrinkage occurring during cement hydration, empty pores are created within the cement paste, leading to a reduction in its internal relative humidity and also to shrinkage which may cause early-age cracking.

\subsection{Potential Materials for Internal Curing (IC)}

The following materials can provide internal water reservoirs:

- $\quad$ Lightweight Aggregate (natural and synthetic, expanded shale)

- $\quad$ Super-absorbent Polymers (SAP) (60-300 nm size) 
- $\quad$ SRA (Shrinkage Reducing Admixture) (propylene glycol type i.e. polyethylene-glycol)

\subsection{Advantages of Internal Curing}

- Internal curing (IC) is a method to provide the water to hydrate all the cement, accomplishing what the mixing water alone cannot do.

- Provides water to keep the relative humidity (RH) high, keeping self-desiccation from occurring.

- Eliminates largely autogenous shrinkage.

- Maintains the strengths of mortar/concrete at the early age (12 to $72 \mathrm{hrs}$.) above the level where internally \& externally induced strains can cause cracking.

- Can make up for some of the deficiencies of external curing, both human related (critical period when curing is required in the first 12 to 72 hours) and hydration.

\subsection{Polyethylene Glycol}

Polyethylene glycol is a condensation polymer of ethylene oxide and water with the general formula $\mathrm{H}\left(\mathrm{OCH}_{2} \mathrm{CH}_{2}\right)_{\mathrm{n}} \mathrm{OH}$, where $\mathrm{n}$ is the average number of repeating oxyethylene groups typically from 4 to about 180 . The abbreviation (PEG) is termed in combination with a numeric suffix which indicates the average molecular weights. One common feature of PEG appears to be the water-soluble nature. Polyethylene glycol is non-toxic, odorless, neutral, lubricating, non-volatile and non-irritating and is used in a variety of pharmaceuticals. The behaviour of Polyethylene glycol is shown in Fig 1.

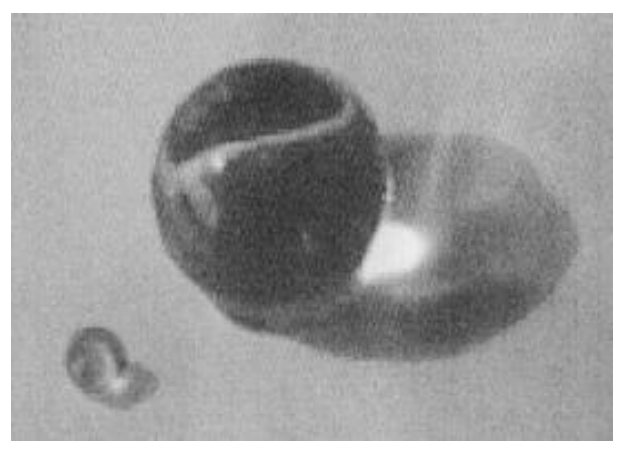

Fig1. Behaviour of Polyethylene glycol

\section{LITERATURE REVIEW}

Ole and Hansen describe a new concept for the prevention of self-desiccation in hardening cement-based materials using fine, super absorbent polymer (SAP) particles as a concrete admixture. The SAP will absorb water and form macro inclusions and this leads to water entrainment, i.e. the formation of water-filled macro pore inclusions in the fresh concrete. Consequently, the pore structure is actively designed to control self-desiccation. In this work, self-desiccation and water entrainment are described and discussed.
Roland Tak Yong Liang, Robert Keith Sun carried work on internal curing composition for concrete which includes a glycol and a wax. The invention provides for the first time an internal curing composition which, when added to concrete or other cementitious mixes meets the required standards of curing as per Australian Standard AS 3799.

Wen-Chen Jau stated that self curing concrete is provided to absorb water from moisture from air to achieve better hydration of cement in concrete. It solves the problem when the degree of cement hydration is lowered due to no curing or improper curing by using self curing agent like poly-acrylic acid which has strong capability of absorbing moisture from atmosphere and providing water required for curing concrete.

A.S. El-Dieb investigated water retention of concrete using water-soluble polymericglycol as self-curing agent. Concrete weight loss and internal relative humidity measurements with time were carried out, in order to evaluate the water retention of self-curing concrete. Water transport through concrete is evaluated by measuring absorption $\%$, permeable voids $\%$, water sorptivity and water permeability. The water transport through self-curing concrete is evaluated with age.The effect of the concrete mix proportions on the performance of selfcuring concrete were investigated, such as, cement content and water/cement ratio.

PietroLura The main aim of his study was to reach a better comprehension of autogenous shrinkage in order to be able to model it and possibly reduce it. Once the important role of self-desiccation shrinkage in autogenous shrinkage is shown, the benefits of avoiding self-desiccation through internal curing become apparent.

\section{SCOPE AND OBJECTIVE}

- The scope of the paper is to study the effect of polyethylene glycol (PEG 400) on strength characteristics of Self-curing concrete

- The objective is study the mechanical characteristics of concrete such as compressive strength, split tensile strength and modulus of rupture by varying the percentage of PEG from $0 \%$ to $2 \%$ by weight of cement for both M20 and M40 grades of concrete.

\section{EXPERIMENTAL PROGRAMME}

The experimental program was designed to investigate the strength of self curing concrete by adding poly ethylene glycol PEG400@0.5\%,1\%,1.5\% and 2\% by weight of cement to the concrete. The experimental program was aimed to study the workability, compressive strength, split tensile strength and modulus of rupture. To study the above properties mixes M20 and M40 were considered. The scheme of experimental program is given in Table No.1 
Table 1: Details of specimens cast.

\begin{tabular}{|c|c|c|c|c|c|c|c|}
\hline \multirow{2}{*}{$\begin{array}{c}\text { SL } \\
\text { No }\end{array}$} & \multirow{2}{*}{$\begin{array}{c}\text { Natur } \\
\mathrm{e}\end{array}$} & \multicolumn{3}{|c|}{ M20 } & \multicolumn{3}{|c|}{ M40 } \\
\hline & & $\begin{array}{l}\mathrm{Cu} \\
\mathrm{be}^{*}\end{array}$ & 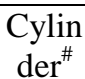 & $\begin{array}{c}\text { Pris } \\
\mathrm{m}^{\$}\end{array}$ & $\begin{array}{l}\mathrm{Cu} \\
\text { be }\end{array}$ & $\begin{array}{c}\text { Cylin } \\
\text { der }\end{array}$ & \begin{tabular}{|c|} 
Pris \\
$\mathrm{m}$
\end{tabular} \\
\hline 1 & Plain & 3 & 3 & 3 & 3 & 3 & 3 \\
\hline 2 & $0.5 \%$ & 3 & 3 & 3 & 3 & 3 & 3 \\
\hline 3 & $1 \%$ & 3 & 3 & 3 & 3 & 3 & 3 \\
\hline 4 & $1.5 \%$ & 3 & 3 & 3 & 3 & 3 & 3 \\
\hline 5 & $2 \%$ & 3 & 3 & 3 & 3 & 3 & 3 \\
\hline
\end{tabular}

*The size of each cube is $150 \times 150 \times 150 \mathrm{~mm}$.

\# The size of each cylinder is $150 \mathrm{~mm}$ in dia and $300 \mathrm{~mm}$ in height.

\$ The size of each prism is $100 \times 100 \times 400 \mathrm{~mm}$

\section{MATERIALS USED}

The different materials used in this investigation are

5.1 Cement: Cement used in the investigation was 53 grade ordinary Portland cement confirming IS: 12269: 1987.

5.2 Fine aggregate: The fine aggregate used was obtained from a near byriver source. The fine aggregate conforming to zone III according to IS: 383-1970 was used.

5.3 Coarse aggregate: Crushed granite was used as coarse aggregate. The coarse aggregate according to IS: $383-1970$ was used. Maximum coarse aggregate size used is $20 \mathrm{~mm}$.

5.4 Polyethylene Glycol-400: Polyethylene glycol is a condensation polymer of ethylene oxide and water with the general formula $\mathrm{H}\left(\mathrm{OCH}_{2} \mathrm{CH}_{2}\right)_{n} \mathrm{OH}$, where $\mathrm{n}$ is the average number of repeating oxyethylenegroups typically from 4 to about 180. The abbreviation (PEG) is termed in combination with anumeric suffix which indicates the average molecular weight. One common feature of PEG appears to be the watersoluble nature. The PEG-400 use in the investigation have Molecular Weight 400, Appearance Clear liquid, pH 5-7, Specific Gravity 1.126

5.5 Water: Potable water was used in the experimental work for both mixing and curing purposes.

\section{CASTING PROGRAMME:}

Casting of the specimens were done as per IS:10086-1982, preparation of materials, weighing of materials and casting of cubes, cylinders, beams. The mixing, compacting and curing of concrete are done according to IS 516: 1959. The plain samples of cubes, cylinders and prisms were cured for 28 days in water pond and the specimens with PEG400 were cured for 28 days at room temperature by placing them in shade. The M20 and M40 grades of concrete are designed and the material required per cubic meter of concrete is shown in Table 2 .

Table 2: Materials required per cubic meter of concrete

\begin{tabular}{|c|c|c|c|c|c|}
\hline $\begin{array}{c}\text { SL } \\
\text { No }\end{array}$ & Mix & $\begin{array}{c}\text { Cement } \\
(\mathrm{kg})\end{array}$ & $\begin{array}{c}\text { Fine } \\
\text { Aggregate } \\
(\mathrm{kg})\end{array}$ & $\begin{array}{c}\text { Coarse } \\
\text { Aggregate } \\
(\mathrm{kg})\end{array}$ & $\begin{array}{c}\text { Water } \\
(\mathrm{kg})\end{array}$ \\
\hline 1 & $\mathrm{M} 20$ & 340 & 610 & 1300 & 187 \\
\hline 2 & $\mathrm{M} 40$ & 440 & 520 & 1220 & 154 \\
\hline
\end{tabular}

\section{TESTING}

\subsection{Slump Test \& Compaction Factor.}

Slump test is the most commonly used method of measuring consistency of concrete which can be employed either in laboratory or at site of work. It does not measure all factors contributing to workability. However, it is used conveniently as a control test and gives an indication of the uniformity of concrete from batch to batch. The compacting factor test is designed primarily for use in the laboratory but it can also be used in the field. It is more precise and sensitive than the slump test and particularly useful for concrete mixes of very low workability as are normally used when concrete is to be compacted by vibration. Such dry concretes are insensitive to slump test.

\subsection{Compressive strength:}

The cube specimens were tested on compression testing machine of capacity $3000 \mathrm{KN}$. The bearing surface of machine was wiped off clean and sand or other material removed from the surface of the specimen. The specimen was placed in machine in such a manner that the load was applied to opposite sides of the cubes as casted that is, not top and bottom. The axis of the specimen was carefully aligned at the centre of loading frame. The load applied was increased continuously at a constant rate until the resistance of the specimen to the increasing load breaks down and no longer can be sustained. The maximum load applied on specimen was recorded.

$\mathrm{f}_{\mathrm{c}}=\mathrm{P} / \mathrm{A}$, where, $\mathrm{P}$ is load \& $\mathrm{A}$ is area

\subsection{Split tensile strength:}

The cylinder specimens were tested on compression testing machine of capacity $3000 \mathrm{KN}$. The bearing surface of machine was wiped off clean and looses other sand or other material removed from the surface of the specimen. The load applied was increased continuously at a constant rate until the resistance of the specimen to the increasing load breaks down and no longer can be sustained. The maximum load applied on specimen was recorded.

$\mathrm{f}_{\text {split }}=2 \mathrm{P} / \pi \mathrm{DL}$, where $\mathrm{P}=$ load, $\mathrm{D}=$ diameter of cylinder, 
$\mathrm{L}=$ length of the cylinder

\subsection{Modulus of rupture:}

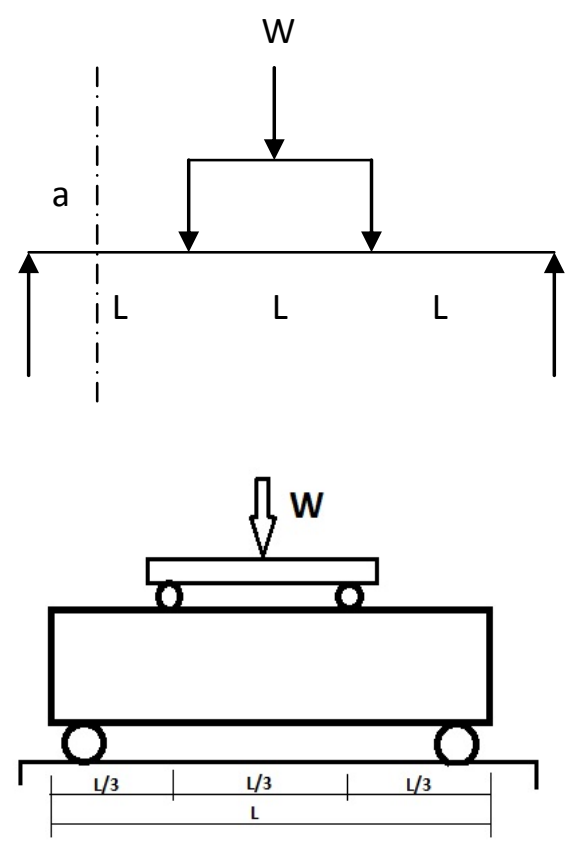

The beam specimens were tested on universal testing machine for two-point loading to create a pure bending. The bearing surface of machine was wiped off clean and sand or other material is removed from the surface of the specimen. The two point bending load applied was increased continuously at a constant rate until the specimen breaks down and no longer can be sustained. The maximum load applied on specimen was recorded. The test set-up is shown in Fig. 2. The modulus of rupture depends on where the specimen breaks along the span. The specimens while testing compressive strength, split tenslie \& Modulus of ruptrure is shown in Fig 3.

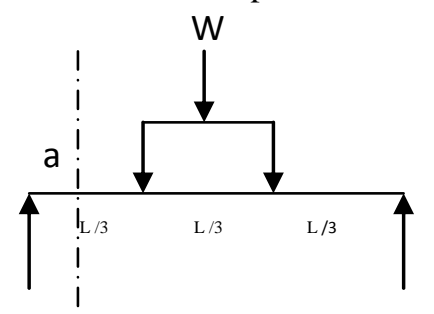

Fig 2. Test set-up for modulus of rupture

If the specimen breaks at the middle third of the span then the modulus of rupture is given by

$\mathrm{f}_{\text {rup. }}=(\mathrm{WL}) /\left(\mathrm{bd}^{2}\right)$
If the specimen breaks at a distance of 'a' from any of the supports then the modulus of rupture is given by

$\mathrm{f}_{\text {rup. }}=(3 \mathrm{Wa}) /\left(\mathrm{bd}^{2}\right)$, where $\mathrm{W}=$ load at failure,

$\mathrm{L}=$ length of specimen $(400 \mathrm{~mm})$

$\mathrm{b}=$ width of specimen $(10 \mathrm{~mm})$,

$\mathrm{d}=$ depth of specimen $(100 \mathrm{~mm})$

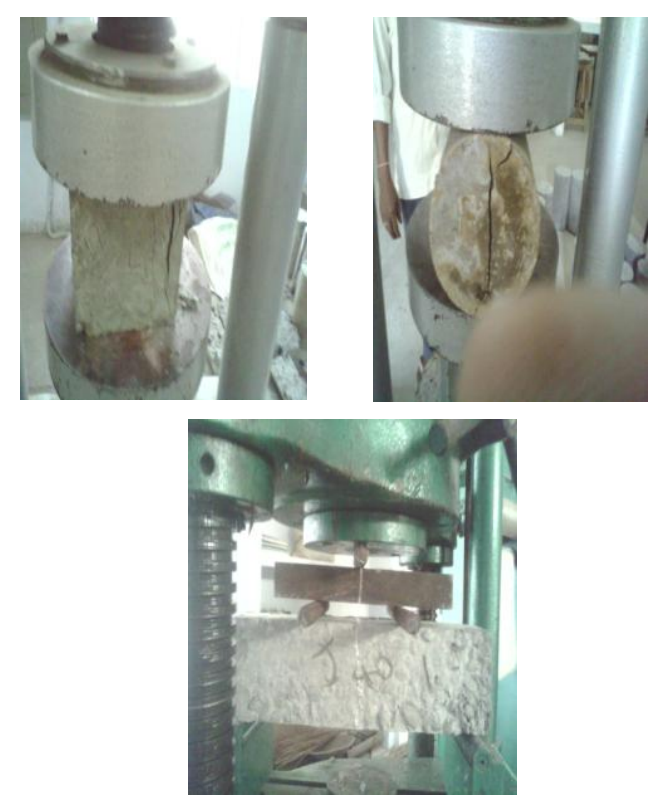

Fig 3: Specimens while testing

\section{RESULTS \& DISCUSSION}

\subsection{Slump and Compaction factor test:}

The results of the Slump \& Compaction factor test were represented in Table 3. The graphical representation of the Slump \& Compaction factor results is shown in Fig 4 and Fig 5 respectively. As the \% of PEG400 is increased the slump and compaction factor is found to increase. But, the rate of increase of slump \& compaction factor for M40 concrete is less than that of M20 plain concrete.

Table 3: Results of Workability

\begin{tabular}{|c|c|c|c|c|c|}
\hline \multirow{2}{*}{$\begin{array}{c}\text { Sl. } \\
\text { No }\end{array}$} & \multirow{2}{*}{$\begin{array}{c}\text { PEG } \\
400\end{array}$} & \multicolumn{2}{|c|}{$\begin{array}{c}\text { Slump } \\
(\mathrm{mm})\end{array}$} & \multicolumn{2}{c|}{$\begin{array}{c}\text { Compaction } \\
\text { Factor }\end{array}$} \\
\cline { 3 - 6 } & & M20 & M40 & M20 & M40 \\
\hline 1 & Plain & 80 & 45 & 0.88 & 0.85 \\
\hline 2 & $0.50 \%$ & 92 & 65 & 0.90 & 0.87 \\
\hline 3 & $1.00 \%$ & 112 & 95 & 0.91 & 0.90 \\
\hline 4 & $1.50 \%$ & 140 & 130 & 0.93 & 0.91 \\
\hline 5 & $2.00 \%$ & 175 & 160 & 0.96 & 0.94 \\
\hline
\end{tabular}




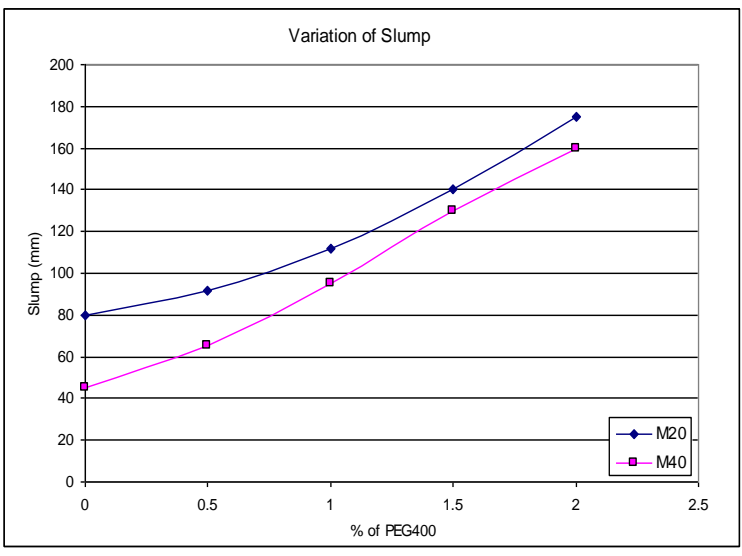

Fig 4. Variation of Slump

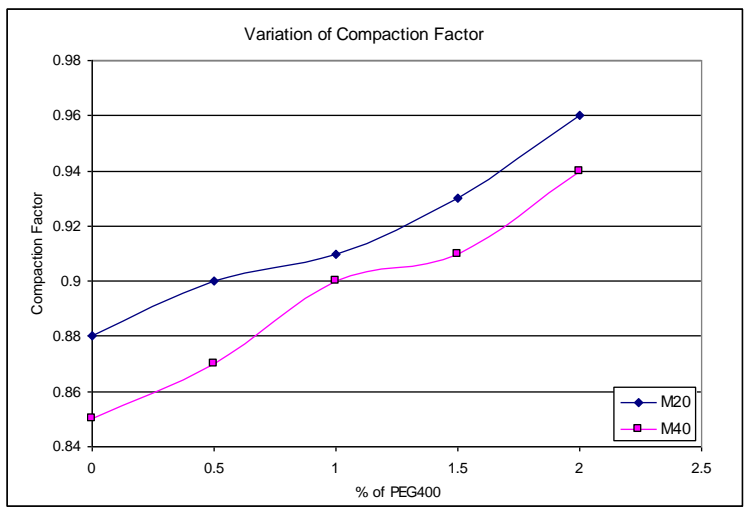

Fig 5. Variation of Compaction Factor

\subsection{Compressive Strength:}

The results of the compressive strength are represented in Table 4 and the graphical representation is shown in Fig 6. The compressive strength was found to increase up to $1 \%$ PEG400 and then decreased for M20 grade. In the case of M40 compressive strength increased up to $0.5 \%$ and then decreased. The increase in compressive strength was $7.23 \%$ at $1 \%$ of PEG 400 compared to conventional concrete for M20, while the increase is $1.24 \%$ at $0.5 \%$ of PEG400 in case of M40 grade of concrete.

\begin{tabular}{|c|c|c|c|c|c|c|c|}
\hline \multirow{2}{*}{$\begin{array}{c}\text { Sl. } \\
\text { No }\end{array}$} & \multirow{2}{*}{ PEG } & \multicolumn{2}{|c|}{$\mathrm{f}_{\mathrm{c}}\left(\mathrm{N} / \mathrm{mm}^{2}\right)$} & \multicolumn{2}{|c|}{$\mathrm{f}_{\text {split }}\left(\mathrm{N} / \mathrm{mm}^{2}\right)$} & \multicolumn{2}{|c|}{$\mathrm{f}_{\text {rup }}\left(\mathrm{N} / \mathrm{mm}^{2}\right)$} \\
\cline { 3 - 8 } & & M20 & M40 & M20 & M40 & M20 & M40 \\
\hline 1 & Plain & 26.60 & 46.65 & 1.81 & 2.42 & 3.50 & 4.62 \\
\hline 2 & $0.50 \%$ & 27.61 & 47.23 & 1.96 & 2.50 & 3.75 & 4.75 \\
\hline 3 & $1.00 \%$ & 28.49 & 45.93 & 2.02 & 2.45 & 3.80 & 4.64 \\
\hline 4 & $1.50 \%$ & 26.74 & 44.62 & 1.92 & 2.34 & 3.68 & 4.53 \\
\hline 5 & $2.00 \%$ & 25.03 & 42.44 & 1.85 & 2.25 & 3.55 & 4.46 \\
\hline
\end{tabular}

Table 4: Mechanical Properties

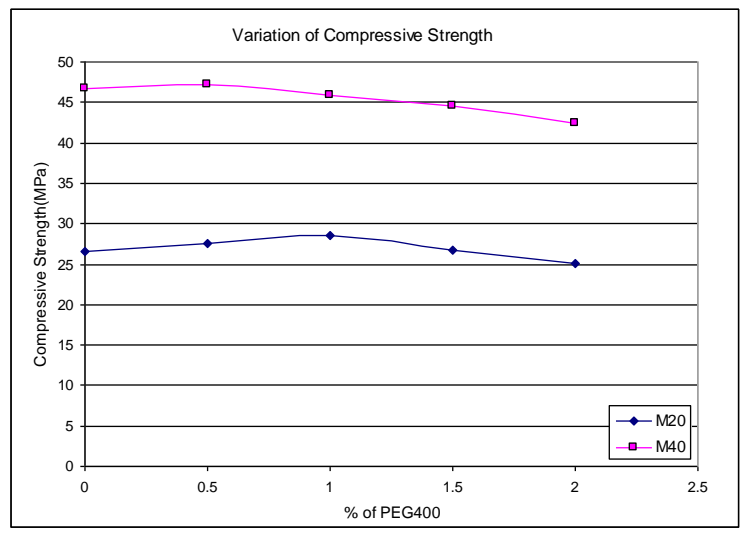

Fig 6. Variation of Compressive Strength

\subsection{Split Tensile Strength:}

The results of the split tensile strength are represented in Table 4 and the graphical representation is shown in Fig 7. The split tensile strength was found to increase up to $1 \%$ PEG400 and then decreased for M20 grade. In the case of M40 split tensile strength increased up to $0.5 \%$ and then decreased. The increase in split tensile strength was $11.60 \%$ at $1 \%$ of PEG400 compared to conventional concrete for M20, while the increase is $3.30 \%$ at $0.5 \%$ of PEG400 in case of M40 grade of concrete.

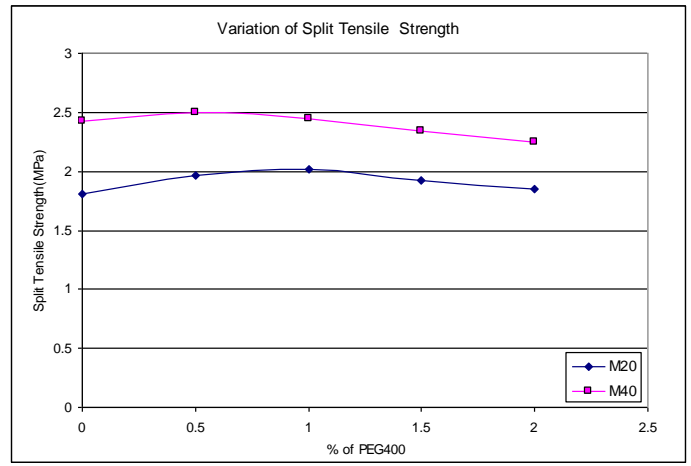

Fig7. Variation of Split Tensile Strength

\subsection{Modulus of rupture:}

The results of the modulus of rupture are represented in Table 4 and the graphical representation is shown in Fig 8. The modulus of rupture was found to increase up to $1 \%$ PEG400 and then decreased for M20 grade. In the case of M40 modulus of rupture increased up to $0.5 \%$ and then decreased. The increase in modulus of rupture was $8.57 \%$ at $1 \%$ of PEG 400 compared to conventional concrete for M20, while the increase is $2.81 \%$ at $0.5 \%$ of PEG400 in case of M40 grade of concrete. 


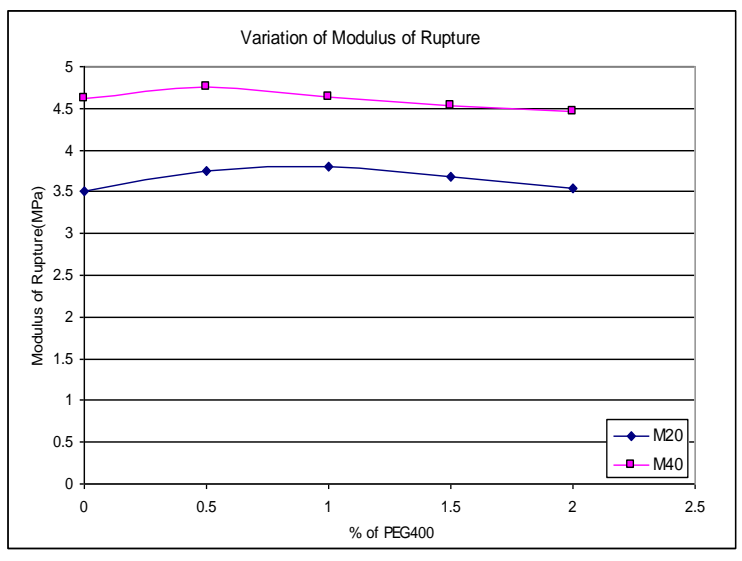

Fig 8. Variation of Modulus of Rupture

\section{CONCLUSIONS}

1. The optimum dosage of PEG400 for maximum strengths (compressive, tensile and modulus of rupture) was found to be $1 \%$ for M20 and $0.5 \%$ for M40 grades of concrete.

2. As percentage of PEG400 increased slump increased for both M20 and M40 grades of concrete.

3. Strength of self curing concrete is on par with conventional concrete.

4. Self curing concrete is the answer to many problems faced due to lack of proper curing.

\section{REFERENCES:}

[1] Bentz, D.P., "Capillary Porosity Depercolation/Repercolation in Hydrating Cement Pastes via Low Temperature Calorimetry Measurements and CEMHYD3D Modeling," Journal of the American Ceramic Society, 89 (8), 2606-2611, 2006.

[2] Bentz, D.P., "Influence of Curing Conditions on Water Loss and Hydration in Cement Pastes with and without Fly Ash Substitution," NISTIR 6886, U.S. Dept. Commerce, July 2002.

[3] Bentz, D.P., and Snyder, K.A., "Protected Paste Volume in Concrete: Extension to Internal Curing Using Saturated Lightweight Fine Aggregates," Cement and Concrete Research. 29, 1863-1867, 1999.

[4] Bentz, D.P., and Stutzman, P.E., "Curing, Hydration, and Microstructure of Cement Paste," ACI Materials Journal, 103 (5), 348-356, 2006.

[5] Bentz, D.P., Garboczi, E.J., and Snyder, K.A., "A Hard Core/Soft Shell Microstructural Model for Studying Percolation and Transport in Three-Dimensional Composite Media," NISTIR 6265, U.S. Department of Commerce, 1999.

[6] Bentz, D.P., Halleck, P.M., Grader, A.S., and Roberts, J.W., "Direct Observation of Water Movement during Internal Curing Using X-ray Microtomography," Concrete International, 28 (10), 39-45, 2006.
[7] Bentz, D.P., Lura, P., and Roberts, J.W., "Mixture Proportioning for Internal Curing," Concrete International, 27 (2), 35-40, 2005.

[8] Bilek, B et al, "The possibility of self-curing concrete Proc Name Innovations and developments in concrete materials and construction." Proc. Intl Conf. University of Dundee, UK. 9-11 September 2002.

[9] Cusson, D., and Hoogeveen, T., "Internally-Cured High- Performance Concrete under Restrained Shrinkage and Creep," CONCREEP 7 Workshop on Creep, Shrinkage and Durability of Concrete and Concrete Structures, Nantes, France, Sept. 12-14, 2005, pp. 579-584.

[10] De Jesus Cano Barrita, F.; Bremner, T.W.; Balcom, B.J., "Use of magnetic resonance imaging to study internal moist curing in concrete containing saturated lightweight aggregate," High-performance structural lightweight concrete. ACI fall convention, Arizona, October 30, 2002. ACI SP 218.

[11] Dhir, R.K. Hewlett, P.C. Dyer, T.D., "Mechanisms of water retention in cement pastes containing a selfcuring agent, " Magazine of Concrete Research, Vol No 50, Issue No 1, 1998, pp85-90.

[12] Geiker, M.R., Bentz, D.P., and Jensen, O.M., "Mitigating Autogenous Shrinkage by Internal Curing," High Performance Structural Lightweight Concrete, SP-218, J.P. Ries and T.A. Holm, eds., American Concrete Institute, Farmington Hills, MI, 2004, pp. 143-154.

[13] Geiker, M.R.; Bentz, D.P.; Jensen, O.M., "Mitigating autogenous shrinkage by internal curing, Highperformance structural lightweight concrete." ACI fall convention, Arizona, October 30, 2002. ACI SP 218.

[14] Hammer, T.A.; Bjontegaard, O.; Sellevold, E.J., "Internal curingrole of absorbed water in aggregates, High-performance structural lightweight concrete." ACI fall convention, Arizona, October 30, 2002. ACI SP 218.

[15] Hoff, G. C., "The Use of Lightweight Fines for the Internal Curing of Concrete," Northeast Solite Corporation, Richmond, Va., USA, August 20, 2002, $37 \mathrm{pp}$.

[16] Hoff, G.C., "Internal Curing of Concrete Using Lightweight Aggregates," Theodore Bremner Symposium, Sixth CANMET/ACI, International Conference on Durability, Thessaloniki, Greece, June 1-7 (2003).

[17] Kewalramani, M.A.; Gupta, R, "Experimental study of concrete strength through an eco-friendly curing technique," Advances in concrete technology and concrete structures for the future. Dec 18-19, 2003. Annamalainagar.

[18] Kovler, K.; et.al., "Pre-soaked lightweight aggregates as additives for internal curing of high-strength concrete"s, Cement, Concrete and Aggregates, No 2, Dec. 2004, pp 131-138. 
[19] Lura, P., "Autogenous Deformation and Internal Curing of Concrete," Ph.D. Thesis, Technical University Delft, Delft, The Netherlands, 2003.

[20] Mangaiarkarasi, V.; Damodarasamy, S.R., "Self curing concrete today's and tomorrow's need of construction world," INCRAC \& CT 2005-Proc Intl Conf on recent advances in concrete and construction technology. 7-9 December 2005, Chennai. Vol.2.

[21] Mather, B., Hime, W.G., "Amount of Water Required for Complete Hydration of Portland Cement, " Concrete International, Vol. 24, No. 6, June, 56-58 (2002).

[22] Powers, T.C., Brownyard, T.L., "Studies of the Physical Properties of Hardened Portland Cement Paste," Bulletin 22, Portland Cement Association, Skokie, Illinois, 992 pp. (1948).

[23] Troli, R. et al. "Self compacting /curing/compressing concrete, Global Constr. : Ultimate concrete opportunities : Admixtures-enhancing concrete performance." 6th Intl.congress. Univ of Dundee, UK. 5 July 2005.

[24] Zhutovsky, S.; Kovler, K. Bentur, A., "Efficiency of lightweight aggregates for internal curing of high strength concrete to eliminate autogenous shrinkage," Materials and Structures, 35(246)40, 2002, Page 097101. 